\title{
Morphologic and Agronomic Diversity of Brassica napus Crops
}

\author{
Pilar Soengas', Maria Elena Cartea, Pablo Velasco, Guillermo Padilla, and Amando Ordás \\ Department of Plant Genetics, Misión Biológica de Galicia (CSIC), Apartado 28, \\ E-36080 Pontevedra, Spain TLF
}

\begin{abstract}
AdDitional INDEX wORDS. nabicol, couve-nabiça, oilseed rape, rutabaga, phytogenetic resources, germplasm collection
Abstract. A Brassica napus L. crop called nabicol traditionally has been grown by farmers in northwestern Spain for many years and is an important horticultural product during the winter season. The relationship of nabicol to other B. napus crops has been studied based on simple sequence repeat (SSR) data. However, molecular and morphologic classifications often disagree. The objectives of this research were to study the morphologic and agronomic relationships of nabicol landraces to other $B$. napus crops and to compare those relationships with the ones already known, based on SSR data. Thirty-five B. napus populations from different geographic origins and uses were evaluated. Data were recorded on 17 morphologic and agronomic traits. Principal component analysis and cluster analysis were performed to classify the populations. Eight principal components $(94 \%$ of the total variability) were standardized to produce the Mahalanobis' generalized distances, and a cluster analysis was conducted using the unweighted pair group method with arithmetic averages. There are no major differences between $B$. napus var. pabularia (DC.) Rchb. (nabicol, couve-nabiça, forage rape) and B. napus var. oleifera DC. (oilseed rape), and they probably share a common origin. Rape kale (B. napus var. pabularia) and rutabaga [B. napus var. napobrassica (L.) Rchb.] cultivars are separated from the rest and probably they have an independent origin or domestication. Molecular and morphologic classifications are complementary, and both are necessary to classify germplasm correctly and to clarify genetic relationships among $B$. napus crops.
\end{abstract}

The species Brassica napus includes economically important vegetable and fodder crops, such as oilseed rape, rutabaga, and leaf rape. A B. napus crop called nabicol has been grown by farmers in northwestern Spain for many years, and is an important horticultural product during the winter season (Cartea et al., 2005). The leaves are used for human consumption and fodder. Nabicol landraces have been collected since the 1980s in northwestern Spain in those areas where the crop is important, mainly on the border of Portugal. Populations have been kept as an active collection at the 'Misión Biológica de Galicia' [Consejo Superior de Investigaciones Científicas (CSIC), Pontevedra, Spain] (Ordás and Baladrón, 1985).

The agronomic and morphologic characteristics of this collection have been studied by Rodríguez et al. (2005). The nabicol landraces showed a good agronomic performance, similar to that of commercial nabicol checks, and some of them are promising for fresh production (Rodríguez et al., 2005). Information about genetic relationships of nabicol to other B. napus crops could be useful in designing breeding programs to obtain improved nabicol populations. Cartea et al. (2005) classified 33 nabicol populations and 16 British B. napus populations of forage rape and rape kale using random amplified polymorphic DNA markers and concluded that Spanish and British populations have an independent origin. Soengas et al. (2006) compared nabicol with other B. napus crops with a different end use (oilseed rape, rutabaga, and leafy

Received for publication 8 May 2007. Accepted for publication 6 Sept. 2007. Research was supported by the Committee for Science and Technology of Spain (Project Cod. AGL2006-04055) and Excma. Diputación Provincial de Pontevedra, Spain. P.S. acknowledges a grant from the I3P Program of the Consejo Superior de Investigaciones Científicas, Spain. G.P. acknowledges a fellowship from the Cabildo Insular de la Palma, Spain.

We thank Elisa Santiago and Rosaura Abilleira for their invaluable help.

${ }^{1}$ Corresponding author. E-mail: psoengas@mbg.cesga.es. crops) using simple sequence repeat (SSR) markers and concluded that genetic differences are not related to the use of the crop, but they could reflect differences in their origin instead. Spanish nabicol seems to be closely related to the Portuguese couve-nabiça, a vegetable B. napus crop, which suggests that nabicol and couve-nabiça have a common origin (Soengas et al., 2006). To confirm the genetic relationships of nabicol populations with other $B$. napus crops with a different end use, a morphologic classification of the same germplasm studied by Soengas et al. (2006) is required, because molecular and morphologic classifications often disagree. The objectives of this research were to study the morphologic and agronomic relationships of nabicol landraces to other B. napus crops and to compare those relationships with the ones already known, based on SSR data.

\section{Materials and Methods}

Plant material. Thirty-five $B$. napus populations from different geographic origins and representing different uses of this species were evaluated, including landraces and commercial populations (Table 1). Accessions were obtained from the gene banks of the following centers: Misión Biológica de Galicia, Pontevedra, Spain; Horticulture Research International, Wellesbourne, UK; and Center for Genetic Resources, Wageningen, The Netherlands. To facilitate the description of the material, populations were divided into four sets based on their end use (leafy crops, oilseed crops, root vegetable crops, and populations with unknown use). The first group was formed by nabicol landraces, couve-nabiça populations, and five populations of forage rape and rape kale from diverse origins. Nabicol landraces are from northwestern Spain and they were chosen to represent the clusters obtained in previous morphologic and molecular characterizations (Cartea et al., 2005; 
Table 1. List of 35 Brassica napus accessions/populations included in this study, their country of origin, common name, type, and seed source. Included are comparison of the clusters obtained for 35 Brassica napus populations studied based on 17 morphological and agronomic data, and the clusters obtained for the same set of populations based on 16 simple sequence repeat markers.

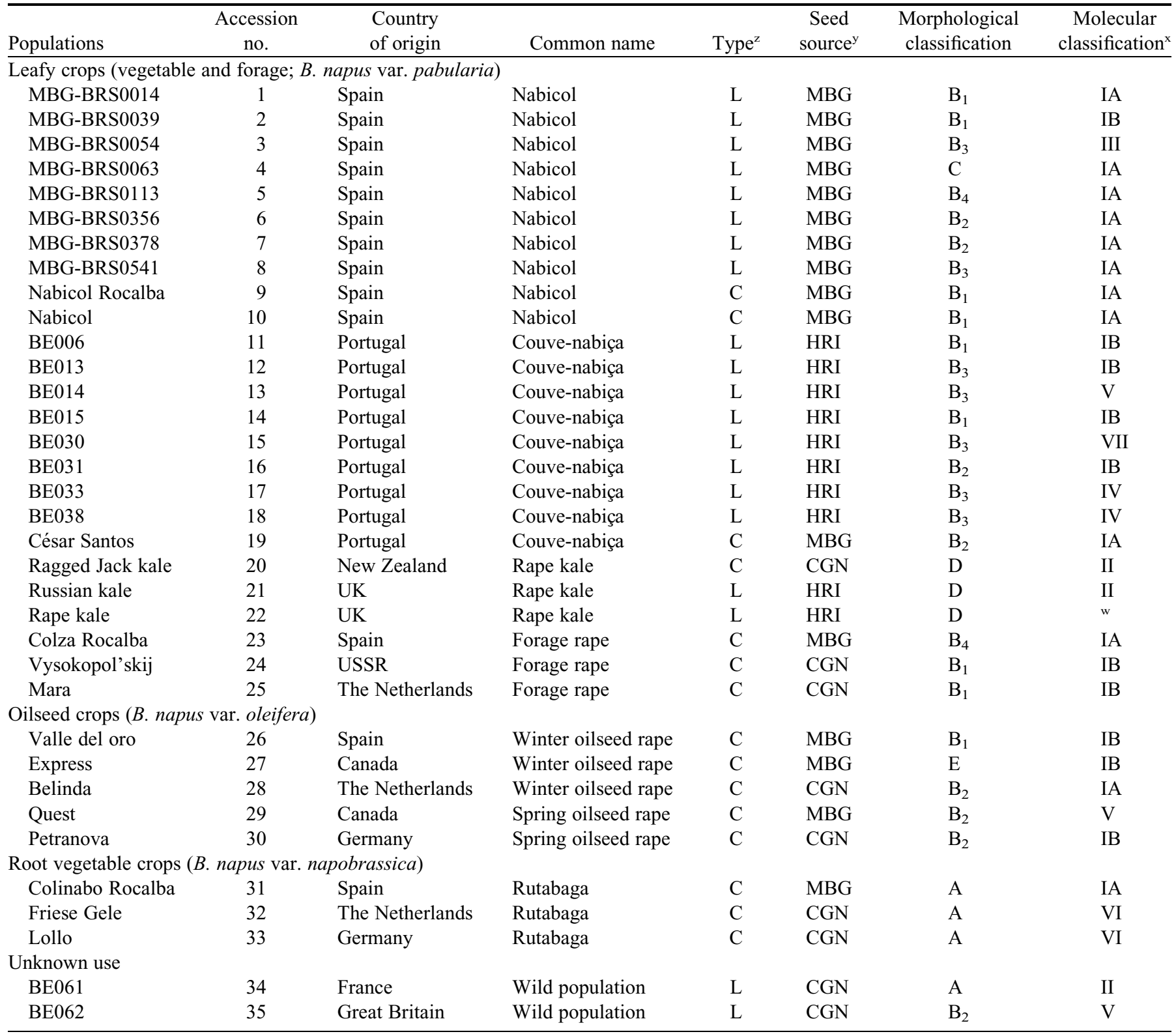

${ }^{\mathrm{z}} \mathrm{C}$, commercial; L, landrace.

${ }^{y}$ CGN, Center for Genetic Resources, Wageningen, The Netherlands; HRI, Horticulture Research International, Wellesbourne, UK; MBG, Misión Biológica de Galicia, Pontevedra, Spain.

xTaken from Soengas et al. (2006).

wPopulation not analyzed in the molecular classification.

Rodríguez et al., 2005). Populations of couve-nabiça are used for human consumption in Portugal and they were chosen to represent different geographical and climatic conditions of that country. The second set included five oilseed B. napus populations, comprising spring and winter rapeseeds. Finally, the third and fourth sets consisted of rutabaga and "wild" populations respectively (Table 1). Most of the evaluated populations are open-pollinated cultivars, except the oilseed rape cultivars Express and Quest, which are $\mathrm{F}_{1}$ hybrids and thus, comparisons of 'Express' and 'Quest' with the rest of populations should be taken cautiously.
Data collection. The populations were evaluated from Sept. 2004 until July 2005 at two locations in the northwestern Spain: Pontevedra $\left(42^{\circ} 24^{\prime} \mathrm{N}, 8^{\circ} 38^{\prime} \mathrm{W}, 50 \mathrm{~m}\right.$ elevation) and Valongo $\left(42^{\circ} 26^{\prime} \mathrm{N}, 8^{\circ} 27^{\prime} \mathrm{W}, 500 \mathrm{~m}\right.$ elevation). The soil type is acid sandy loam. Populations were planted in multipot trays, and seedlings were transplanted into the field at the five- to sixleaf stage. Transplanting dates were on 30 Sept. in Pontevedra and on 13 Oct. in Valongo. Populations were evaluated in a complete randomized block design with three replications. Each experimental plot consisted of two rows with 10 plants per row. Rows were spaced $0.9 \mathrm{~m}$ apart, and plants between 
rows were $0.6 \mathrm{~m}$ apart. Cultural operations, fertilization, and weed control were conducted according to local practices.

Data were recorded on 17 morphologic and agronomic traits adapted from the International Board for Plant Genetic Resources Brassica L. and Raphanus L. descriptors list (International Board for Plant Genetic Resources, 1990). Early vigor was recorded 1 month after transplanting on a visual scale from 1 to $5 \mathrm{pt}$, where $1 \mathrm{pt}$ is very poor development and 5 points is excellent. Some traits were taken on leaves at the vegetative stage: leaf morphology (scale from 1-4 pt, where $1 \mathrm{pt}$ is leaves with straight margins and $4 \mathrm{pt}$ is leaves with divided and wavy margins), leaf size and leaf number (measured on a scales from 1-9, where $9 \mathrm{pt}$ is the highest magnitude), and leaf weight (dry weight in grams of 25 leaves randomly chosen from each plot). At this stage, some traits related to plant development were taken from 10 plants per plot: number of secondary stems per plant, plant height (centimeters), plant diameter (centimeters), and vegetative stem length (centimeters). Phenological data (days to flowering, period of flowering, days to formation of siliques, and days to maturity of siliques) were also measured. At grain maturity, traits related to the seed yield were also recorded on 10 plants per plot: silique number (average number of siliques on the $20 \mathrm{~cm}$ below the top of the main stem), silique length (average length of 20 siliques measured in centimeters), number of seeds per silique, and weight of 1000 seeds (grams).

STATistics. A combined analysis of variance across locations was made. Populations were considered as fixed factors whereas locations, replications, and the location $\times$ population interaction were considered random factors. Comparisons of means were performed for each trait using Fisher's protected LSD at $P=0.05$ (Steel et al., 1997). Analyses were carried on with the GLM procedure of SAS (version 8; SAS Institute, Cary, NC).

Principal component analysis and cluster analysis were performed (Sneath and Sokal, 1973) to classify the populations. Eight principal components were standardized to produce Mahalanobis' generalized distances. This distance eliminates scalar differences between traits (Pkana et al., 2007). A cluster analysis was made using the unweighted pair group method with arithmetic averages (Sneath and Sokal, 1973). All computations were carried on using the NTSYS-PC (ver. 2.1) package (Rohlf, 2000).

\section{Results and Discussion}

Analysis of variance showed that populations were significantly different for all traits (data not shown). The nabicol landrace MBG-BRS00378 showed the highest value of leaf weight (Table 2). Two other nabicol landraces (MBGBRS0063 and Nabicol), one forage rape (Rape kale) and one couve-nabiça (BE015), did not significantly differ from MBGBRS00378 (Table 2). MBG-BRS00378 also showed the highest leaf size and leaf number, and high values of plant height, plant diameter, and vegetative stem length. MBG-BRS0063 did not significantly differ from MBG-BRS00378 for leaf size and leaf number and also showed a good early vigor (Table 2). In a previous characterization of nabicol landraces, MBG-BRS0063 showed better agronomic performance and leaf weight than commercial populations (Rodríguez et al., 2005). Landraces MBG-BRS00378 and MBG-BRS0063 can be considered promising populations that could be used directly by growers to obtain leaves for human consumption or fodder or could be included in breeding programs. The rutabaga 'Friese Gele' showed the lowest leaf weight and the other two rutabaga cultivars (Colinabo Rocalba and Lollo), the rapeseed cultivars Express, Vysokopol'skij and Valle del oro, and the couvenabiça BE030 did not significantly differ from 'Friese Gele'. The rapeseed cultivars Belinda and Petranova showed a good leaf weight, better than some of the leafy crops (Table 2).

The commercial rapeseed cultivar Valle del oro had the highest weight of 1000 seeds (Table 3). Two couve-nabiça cultivars (César Santos and BE030), and the rapeseed cultivar Quest, did not significantly differ from 'Valle del oro', and they also showed a high number of seeds per silique. MBGBRS0113 and 'Nabicol' had a high silique number, silique length, and seeds per silique (Table 3). They also showed an intermediate weight of 1000 seeds. In a previous work, both nabicol landraces showed a high oil content (unpublished data) and, therefore, they could also be used as an oilseed crop. There was no clear separation among leafy and oilseed crops, because some leafy crops have a good seed yield and some oilseed crops have a good leaf weight.

The eight principal components (PCs) with an eigenvalue larger than 0.37 accounted for $94 \%$ of the total variability. Mahalanobis' distances were computed with these PCs. Populations were grouped on five clusters for a Mahalanobis' distance of 3.9 (Fig. 1). The three rutabaga cultivars and the wild population BE061 were on cluster A. This cluster included late populations with low leaf weight, low leaf number, small leaves with straight margins, and few secondary stems. Most nabicol, couve-nabiça, forage rape, and oilseed rape cultivars were grouped on cluster B. Populations in this cluster showed high number of siliques and a high weight of 1000 seeds. This was the biggest cluster, including 24 populations, and it was divided into four subclusters for a Mahalanobis' distance of 3.4 (Fig. 1). Three oilseed rape cultivars were classified on cluster $\mathrm{B}_{2}$ whereas subclusters $\mathrm{B}_{1}, \mathrm{~B}_{3}$, and $\mathrm{B}_{4}$ were formed almost exclusively by leafy cultivars. The nabicol landrace MBGBRS0063 was separated from the rest of the populations in cluster $\mathrm{C}$; this landrace has good early vigor and high leaf weight, large number of leaves, and large leaves. Cluster D included three rape kale cultivars with a low number of secondary stems, a high number of siliques, but a low number of seeds per silique. Their leaves are divided with wavy margins. Finally, cluster E contains one cultivar, the winter oilseed rape 'Express', with poor early vigor and earlier flowering.

Populations were projected on a graph defined by the two PCs (data not shown). The first two PCs accounted for $63.4 \%$ of the variance: $35.7 \%$ on the first and $27.8 \%$ on the second. Considering the coefficients more than 0.7 , the first PC was related to leaf size and leaf number, plant height, length of vegetative stem, leaf weight, and plant diameter. Considering coefficients more than 0.6 , the second $\mathrm{PC}$ was positively related to the number of secondary stems and the weight of 1000 seeds, and was negatively correlated to days to maturity, days to silique, days to flowering, and flowering period. Clusters A and $\mathrm{D}$ from the dendrogram were also clearly defined on the plot (data not shown); they correspond to the group of rutabaga and rape kale cultivars respectively. Both groups appear close together on the plot. They both have long vegetative cycles, a low number of secondary stems, and a low weight of 1000 seeds. Some early populations ('Express', 'Valle del oro', and 'Vysokopol'skij') were separated from the rest of populations 
Table 2. Means of several morphologic and agronomic traits for 35 populations of B. napus evaluated in two environments in northwestern Spain.

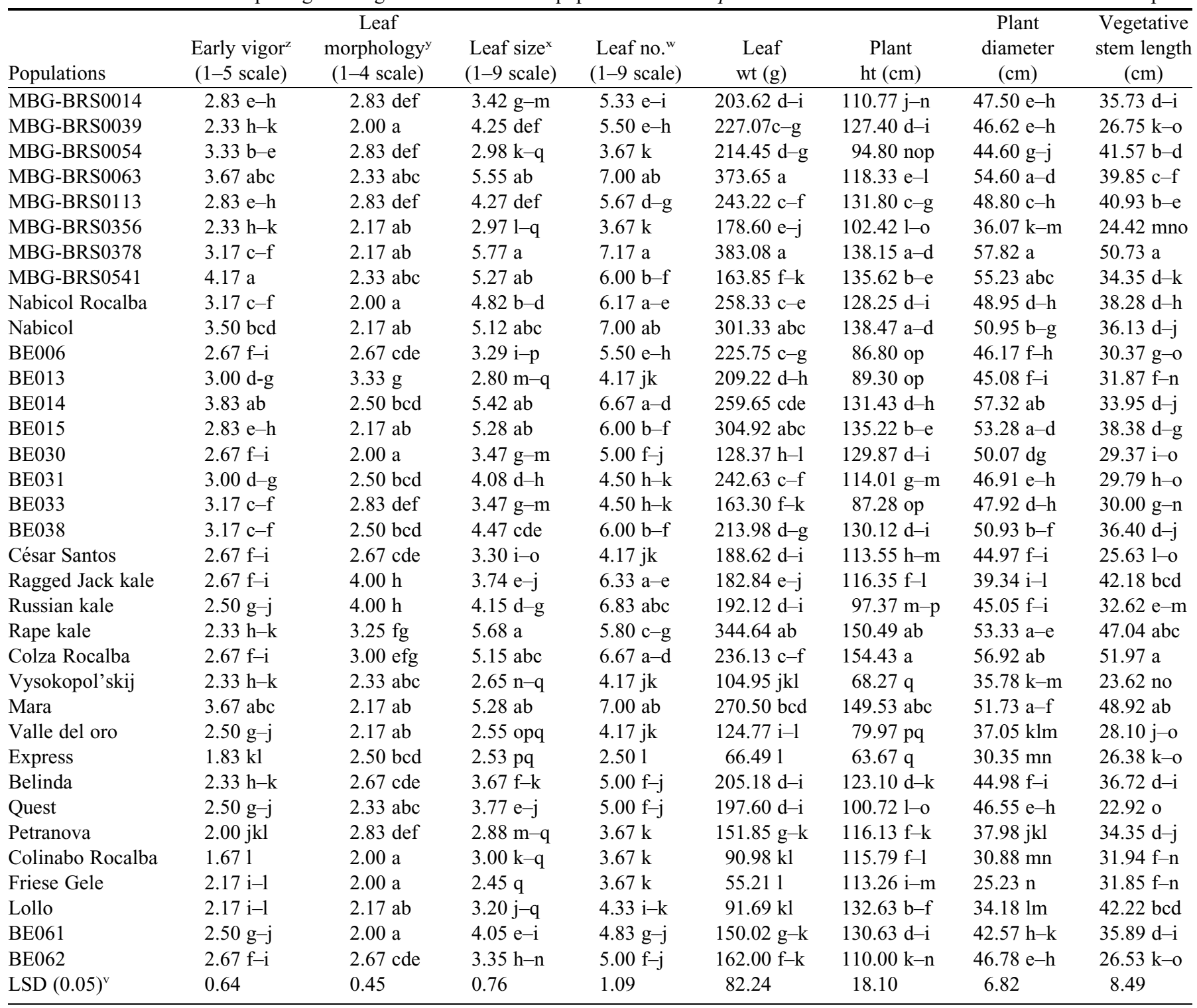

${ }^{\mathrm{z} E a r l y ~ v i g o r: ~} 1 \mathrm{pt}$, very poor; $5 \mathrm{pt}$, excellent.

${ }^{y}$ Leaf morphology: $1 \mathrm{pt}$, leaves with straight margins; 4 pt, leaves with divided and wavy margins.

${ }^{x}$ Leaf size: $1 \mathrm{pt}$, small leaves; 9 pt, big leaves.

${ }^{\mathrm{w}}$ Leaf number: $1 \mathrm{pt}$, small number of leaves; $9 \mathrm{pt}$, large number of leaves.

${ }^{v}$ Means in columns followed by the same letter are not significantly different at $P \leq 0.05$.

because of their poor vegetative development as a consequence of their short cycle. The rest of the oilseed rape cultivars were mixed with leafy crops.

Soengas et al. (2006) made a molecular classification of the same set of B. napus populations using SSR markers. Some comparisons can be made between the dendrogram obtained in this work (Fig. 1) and that reported by Soengas et al. (2006). Table 1 shows the clusters obtained in each study. Cluster A, formed by rutabaga accessions in the morphologic classification, is equivalent to cluster VI in the molecular classification. In the molecular study, 'Colinabo Rocalba' was not with the rest of the rutabaga cultivars, but was in cluster IA close to some nabicol populations, probably as a result of their common genetic background (Soengas et al., 2006). Wild population BE061 grouped with rutabaga cultivars in the morphologic classification, but with rape kale cultivars in the molecular classification. BE061 does not thicken its root and it is probably closer to the rape kale cultivars, but it can be with the rutabaga cultivars because, as mentioned earlier, both groups share some characteristics.

Most nabicol populations are in the same group in both classifications, which supports the idea reported in previous studies, suggesting that nabicol populations have a narrow genetic basis, probably as a result of their common origin (Cartea et al., 2005; Rodríguez et al., 2005; Soengas et al., 2006). In the molecular classification, the nabicol landrace MBG-BRS0054 is separated from the rest of nabicol landraces in group III (Table 1). Soengas et al. (2006) pointed out that this landrace had some SSR bands that were present in couve-nabiça populations, but not in nabicol landraces. In the morphologic 
Table 3. Means of several phenologic and seed yield related traits for 35 populations of B. napus evaluated in two environments in northwestern Spain.

\begin{tabular}{|c|c|c|c|c|c|c|c|c|c|}
\hline Population & $\begin{array}{l}\text { Time to } \\
\text { flowering } \\
\text { (d) }\end{array}$ & $\begin{array}{l}\text { Period of } \\
\text { flowering } \\
\text { (d) }\end{array}$ & $\begin{array}{l}\text { Time to } \\
\text { siliques } \\
\text { (d) }\end{array}$ & $\begin{array}{l}\text { Time to } \\
\text { maturity } \\
\text { (d) }\end{array}$ & $\begin{array}{l}\text { Secondary } \\
\text { stems (no.) }\end{array}$ & $\begin{array}{c}\text { Silique } \\
\text { no. }\end{array}$ & $\begin{array}{l}\text { Silique } \\
\text { length } \\
(\mathrm{cm})\end{array}$ & $\begin{array}{c}\text { Seeds per } \\
\text { silique } \\
\text { (no./silique) }\end{array}$ & $\begin{array}{c}\text { Wt of } 1000 \\
\text { seeds }(\mathrm{g})\end{array}$ \\
\hline MBG-BRS0014 & $162.67 \mathrm{kl}$ & $277.17 \mathrm{pq}$ & $169.83 \mathrm{mn}$ & $247.83 \mathrm{~g}-\mathrm{m}$ & $5.02 \mathrm{e}-\mathrm{h}$ & $25.41 \mathrm{a}-\mathrm{c}$ & $5.80 \mathrm{~m}-\mathrm{r}$ & $13.54 \mathrm{k}-\mathrm{m}$ & $3.94 \mathrm{~g}-\mathrm{k}$ \\
\hline MBG-BRS0054 & $162.00 \mathrm{kl}$ & $275.33 \mathrm{q}$ & $170.671-n$ & $246.67 \mathrm{~g}-\mathrm{m}$ & $5.53 \mathrm{~d}-\mathrm{g}$ & $25.82 \mathrm{ab}$ & $6.35 \mathrm{~g}-\mathrm{n}$ & $20.90 \mathrm{a}-\mathrm{e}$ & $3.72 \mathrm{~h}-1$ \\
\hline MBG-BRS0063 & $179.50 \mathrm{ef}$ & $302.50 \mathrm{~g}-\mathrm{k}$ & $188.17 \mathrm{e}-\mathrm{i}$ & $256.00 \mathrm{c}-\mathrm{g}$ & $4.72 \mathrm{e}-\mathrm{h}$ & $21.90 \mathrm{~d}-\mathrm{k}$ & $7.32 \mathrm{~b}-\mathrm{d}$ & $21.34 \mathrm{a}-\mathrm{c}$ & $3.241-\mathrm{O}$ \\
\hline MBG-BRS0113 & $167.17 \mathrm{i}-\mathrm{k}$ & $275.33 \mathrm{q}$ & $173.00 \mathrm{k}-\mathrm{n}$ & $240.33 \mathrm{k}-\mathrm{O}$ & $4.83 \mathrm{e}-\mathrm{h}$ & $25.09 \mathrm{a}-\mathrm{d}$ & $8.04 \mathrm{a}$ & $21.96 \mathrm{ab}$ & $3.99 \mathrm{e}-\mathrm{k}$ \\
\hline MBG-BRS0378 & $182.00 \mathrm{e}$ & $303.67 \mathrm{f}-\mathrm{k}$ & $191.67 \mathrm{ef}$ & $252.33 \mathrm{~d}-\mathrm{i}$ & $3.73 \mathrm{~h}-\mathrm{k}$ & $19.97 j-n$ & $6.93 \mathrm{c}-\mathrm{g}$ & $16.08 \mathrm{~g}-\mathrm{k}$ & $4.54 \mathrm{a}-\mathrm{f}$ \\
\hline MBG-BRS0541 & $164.67 \mathrm{j}-1$ & 284.50 op & $173.50 \mathrm{k}-\mathrm{n}$ & $243.83 \mathrm{~h}-\mathrm{n}$ & $7.37 \mathrm{a}-\mathrm{c}$ & $24.80 \mathrm{a}-\mathrm{d}$ & $6.84 \mathrm{c}-\mathrm{h}$ & $18.58 \mathrm{bh}$ & $4.06 \mathrm{~d}-\mathrm{k}$ \\
\hline Nabicol Rocalba & $174.83 \mathrm{fg}$ & $295.83 \mathrm{j}-\mathrm{m}$ & $184.67 \mathrm{f}-\mathrm{j}$ & $244.33 \mathrm{~h}-\mathrm{n}$ & $4.12 \mathrm{f}-\mathrm{j}$ & $25.84 \mathrm{ab}$ & $7.38 \mathrm{bc}$ & $20.28 \mathrm{a}-\mathrm{f}$ & $3.81 \mathrm{~h}-1$ \\
\hline Nabicol & $170.67 \mathrm{~g}-\mathrm{i}$ & $288.83 \mathrm{~m}-\mathrm{o}$ & $180.00 \mathrm{~h}-\mathrm{k}$ & $244.17 \mathrm{~h}-\mathrm{n}$ & $4.67 \mathrm{e}-\mathrm{h}$ & $26.20 \mathrm{ab}$ & $7.53 \mathrm{ab}$ & $21.08 \mathrm{a}-\mathrm{e}$ & $3.88 \mathrm{~g}-\mathrm{k}$ \\
\hline BE006 & 159.001 & $272.33 \mathrm{q}$ & $167.83 \mathrm{n}$ & $239.17 \mathrm{~m}-\mathrm{o}$ & $5.82 \mathrm{~b}-\mathrm{f}$ & $23.88 \mathrm{~b}-\mathrm{f}$ & $6.73 \mathrm{e}-\mathrm{i}$ & $20.05 \mathrm{a}-\mathrm{f}$ & $4.01 \mathrm{e}-\mathrm{k}$ \\
\hline BE013 & 159.001 & $271.00 \mathrm{q}$ & $169.50 \mathrm{mn}$ & 236.33 no & $7.97 \mathrm{a}$ & $24.71 \mathrm{a}-\mathrm{d}$ & $6.09 j-p$ & $14.96 \mathrm{i}-1$ & $3.71 \mathrm{~h}-1$ \\
\hline BE033 & 160.171 & $269.00 \mathrm{q}$ & 166.83 no & $238.67 \mathrm{~m}-\mathrm{o}$ & $6.85 \mathrm{a}-\mathrm{d}$ & $23.43 \mathrm{~b}-\mathrm{h}$ & $6.31 \mathrm{~h}-\mathrm{o}$ & $17.51 \mathrm{e}-\mathrm{j}$ & $\mathrm{f}-\mathrm{k}$ \\
\hline BE038 & $171.17 \mathrm{~g}-\mathrm{i}$ & $290.331-0$ & $173.67 \mathrm{k}-\mathrm{n}$ & $241.831-n$ & $a b$ & $20.33 \mathrm{~h}-\mathrm{m}$ & $6.97 \mathrm{~b}-\mathrm{f}$ & $21.20 \mathrm{a}-\mathrm{d}$ & $4.12 \mathrm{c}-\mathrm{j}$ \\
\hline César Santos & $176.00 \mathrm{fg}$ & $302.17 \mathrm{~g}-\mathrm{k}$ & $183.33 \mathrm{f}-\mathrm{j}$ & $252.00 \mathrm{e}-\mathrm{i}$ & $3.54 \mathrm{~h}-\mathrm{k}$ & $19.86 \mathrm{k}-\mathrm{n}$ & $6.78 \mathrm{~d}-\mathrm{i}$ & $21.36 \mathrm{a}-\mathrm{c}$ & $4.61 \mathrm{a}-\mathrm{d}$ \\
\hline Ragged Jack kale & $182.00 \mathrm{e}^{\circ}$ & $314.50 \mathrm{de}$ & $205.33 \mathrm{bc}$ & $266.67 \mathrm{ab}$ & $2.10 \mathrm{k}-\mathrm{m}$ & $22.37 \mathrm{c}-\mathrm{k}$ & $3.47 \mathrm{v}$ & $3.89 \mathrm{n}$ & $3.04 \mathrm{~m}-\mathrm{p}$ \\
\hline Russian kale & $182.00 \mathrm{e}$ & $304.17 \mathrm{f}-\mathrm{j}$ & $189.50 \mathrm{e}-\mathrm{g}$ & $253.00 \mathrm{~d}-\mathrm{h}$ & $2.77 \mathrm{j}-1$ & $25.75 \mathrm{ab}$ & $5.50 \mathrm{q}-\mathrm{t}$ & $13.47 \mathrm{k}-\mathrm{m}$ & $3.59 \mathrm{j}-\mathrm{m}$ \\
\hline Rape kale & $190.00 \mathrm{~d}$ & $320.50 \mathrm{~cd}$ & $195.67 \mathrm{de}$ & $265.17 \mathrm{a}-\mathrm{c}$ & $1.751-\mathrm{n}$ & $23.10 \mathrm{~b}-\mathrm{j}$ & $5.59 \mathrm{p}-\mathrm{t}$ & $15.17 \mathrm{~h}-1$ & 2.95 nop \\
\hline Colza Rocalba & $182.50 \mathrm{e}$ & $306.17 \mathrm{e}-\mathrm{h}$ & $189.33 \mathrm{e}-\mathrm{g}$ & $246.50 \mathrm{~g}-\mathrm{m}$ & $3.78 \mathrm{~g}-\mathrm{k}$ & $27.17 \mathrm{a}$ & $6.61 \mathrm{e}-\mathrm{j}$ & $18.19 \mathrm{c}-\mathrm{i}$ & $3.63 \mathrm{i}-\mathrm{m}$ \\
\hline Vysokopol'skij & $138.67 \mathrm{~m}$ & $257.83 \mathrm{r}$ & $158.00 \mathrm{op}$ & $242.33 \mathrm{i}-\mathrm{n}$ & & $24.51 \mathrm{a}-\mathrm{d}$ & $6.44 \mathrm{f}-1$ & $16.43 \mathrm{~g}-\mathrm{k}$ & $a-f$ \\
\hline Mara & $179.67 \mathrm{ef}$ & $308.00 \mathrm{e}-\mathrm{g}$ & $188.17 \mathrm{e}-\mathrm{i}$ & $254.83 \mathrm{~d}-\mathrm{g}$ & $3.48 \mathrm{~h}-1$ & $23.07 \mathrm{~b}-\mathrm{j}$ & $6.46 \mathrm{f}-1$ & $17.58 \mathrm{e}-\mathrm{j}$ & $3.51 \mathrm{k}-\mathrm{n}$ \\
\hline Valle del oro & $133.00 \mathrm{~m}$ & $239.83 \mathrm{~s}$ & $151.33 \mathrm{p}$ & 236.33 no & $4.35 \mathrm{f}-\mathrm{j}$ & $23.26 \mathrm{~b}-\mathrm{h}$ & $5.15 \mathrm{tu}$ & $11.31 \mathrm{~m}$ & $4.81 \mathrm{a}$ \\
\hline Express & $65.67 \mathrm{n}$ & $155.33 \mathrm{t}$ & $74.17 \mathrm{q}$ & $231.50 \mathrm{o}$ & $4.63 \mathrm{f}-\mathrm{i}$ & 17.06 no & $5.75 \mathrm{o}-\mathrm{s}$ & $13.63 \mathrm{k}-\mathrm{m}$ & $4.14 \mathrm{c}-\mathrm{j}$ \\
\hline BE062 & $178.67 \mathrm{ef}$ & $311.17 \mathrm{ef}$ & $188.83 \mathrm{e}-\mathrm{h}$ & $260.00 \mathrm{~b}-\mathrm{e}$ & $2.77 \mathrm{j}-1$ & $20.44 \mathrm{~h}-\mathrm{m}$ & $5.78 \mathrm{n}-\mathrm{r}$ & $17.86 \mathrm{c}-\mathrm{i}$ & 4.55 af \\
\hline $\operatorname{LSD}(0.05)^{\mathrm{z}}$ & 5.71 & 8.53 & 9.01 & 10.15 & 1.76 & 3.19 & 0.58 & 3.59 & 0.59 \\
\hline
\end{tabular}

${ }^{\mathrm{z}}$ Means in columns followed by the same letter are not significantly different at $P \leq 0.05$.

classification, MBG-BRS0054 is in subcluster $\mathrm{B}_{3}$, close to several couve-nabiça populations (Fig. 1), confirming that the origin of this landrace is probably Portuguese. Based in the molecular similarity among nabicol and couve-nabiça populations, and the fact that couve-nabiça populations showed higher genetic diversity, Soengas et al. (2006) concluded that nabicol populations were derived from couve-nabiça populations and that couve-nabiça populations could be used to improve nabicol populations. In the morphologic classification, nabicol and couve-nabiça populations are together in group B, confirming their common origin.

In both classifications, most of the populations grouped together in a main cluster (cluster B in the morphologic classification and cluster I in the molecular classification). In this cluster, nabicol landraces, couve-nabiça, forage, and oilseed cultivars are mixed, suggesting that there are no major differences among these groups that would be related to their origin or domestication. However, some differences can be found between both classifications. 'Express' and MBGBRS0063 grouped on cluster I based on SSR data whereas both populations classified apart from the rest on clusters $\mathrm{C}$ and E respectively based on morphologic and agronomic data (Table 1). 'Express' has a very poor vegetative development as a consequence of the selection for earliness, and MBGBRS0063 has the best agronomic performance, characteristics that make them different from the rest of populations. 'Colza Rocalba' and 'Nabicol' are very similar in the molecular study. Soengas et al. (2006) hypothesized that they were probably collected in the same or close areas. However, 'Colza Rocalba' classifies far away from 'Nabicol', which is almost identical to 'Nabicol Rocalba' in the morphologic classification. Population BE030 was alone in cluster VII in the molecular classification because it had some alleles that were not present in the rest of populations; however, in the morphologic analysis, it was grouped with other nabicol and couve-nabiça cultivars in subcluster $B_{3}$. Differences 


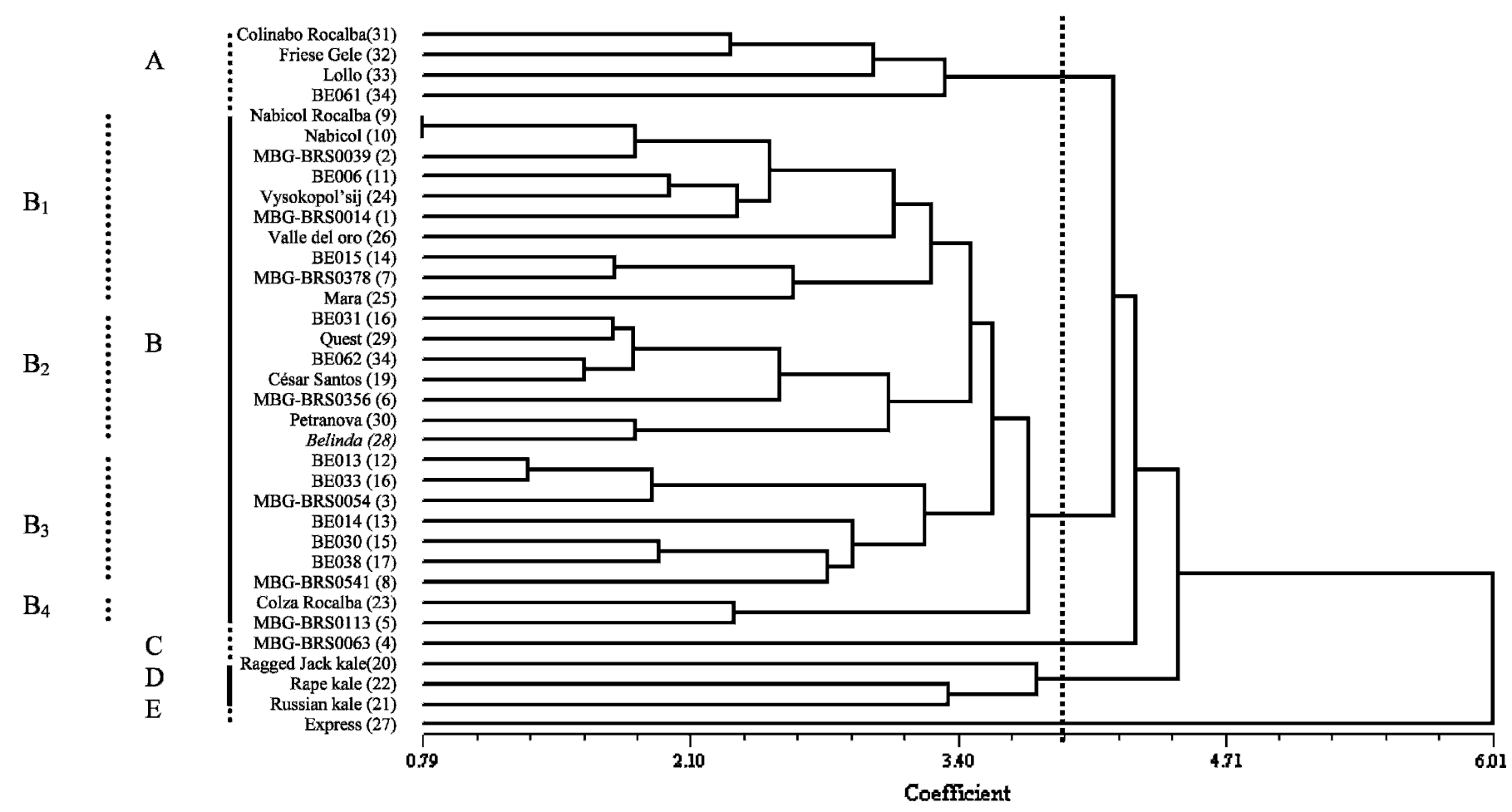

Fig. 1. Dendrogram based on unweighted pair group method with arithmetic averages analysis of the Mahalanobis' distances among 35 Brassica napus populations evaluated at two locations in northwestern Spain, computed using the first eight principal components with an eigenvalue higher than 0.37.

between both classifications can be because the number of SSRs used by Soengas et al. (2006) was not large enough to cover all regions containing the genes controlling the traits for diversity analysis.

Some relationships among cultivars are constant in both dendograms. Rape kale populations appear grouped together in both kinds of classifications, with cluster D based on agronomic data and the cluster II based on SSR data (Table 1). The population rape kale does not appear in the molecular classification because it was not used in that work (Soengas et al., 2006). In previous molecular studies, rape kale cultivars classified apart from other B. napus crops as oilseed and forage rape (Cartea et al., 2005; Hasan et al., 2006; Soengas et al., 2006), and nabicol and couve-nabiça (Cartea et al., 2005; Soengas et al., 2006). Song et al. (1988) and Song and Osborn (1992) proposed multiple origins of B. napus based on restriction fragment length polymorphism analyses. Cytoplasm of rape kale would be more related to $B$. rapa compared with the rest of the B. napus crops (Song et al., 1988; Song and Osborn, 1992).

Some conclusions can be made after comparing both classifications. There are no major differences among nabicol, couve-nabiça, oilseed, and forage rape crops, and they probably share a common origin. Rape kale and rutabaga crops are separated from the rest of the populations in both classifications; they probably have an independent origin or domestication from the rest of the B. napus crops. The hypothesis of multiple origins for B. napus populations has been mentioned before. According to Prakash and Hinata (1980), rutabagas were known to the Greeks, whereas rapes were described in the low countries and England in the 18th century. Schiemann (cited by Gómez-Campo and Prakash, 1999) considered that rutabaga developed from var. oleifera forms by selection, but Olsson (1960), on the basis that rapifera forms can be synthesized directly from crosses between rapifera forms of B. rapa and B. oleracea, hinted at the possibility that rutabaga had swollen roots from its origin. The hypothesis of multiple origins for B. napus populations was later assessed based on molecular markers (Song et al., 1988; Song and Osborn, 1992). This work contributes to this theory.

We can conclude that molecular and morphologic classifications are complementary and necessary to classify germplasms correctly and to clarify genetic relationships among cultivars.

\section{Literature Cited}

Cartea, M.E., P. Soengas, A. Picoaga, and A. Ordás. 2005. Relationships among Brassica napus (L.) germplasm from Spain and Great Britain as determined by RAPD markers. Genet. Resour. Crop Evol. 52:655-662.

Gómez-Campo, C. and S. Prakash. 1999. Origin and domestication, p. 33-58. In: C. Gómez-Campo (ed.). Biology of Brassica coenospecies. Elsevier Science, Amsterdam, The Netherlands.

Hasan, M., F. Seyis, A.G. Badani, J. Pons-Kühnemann, W. Friedt, W. Lühs, and R.J. Snowdon. 2006. Analysis of genetic diversity in the Brassica napus L. gene pool using SSR markers. Genet. Resour. Crop Evol. 52:655-662.

International Board for Plant Genetic Resources. 1990. Descriptors for Brassica and Raphanus. 2 July 2007. <http://www.bioversityinter national.org/Publications/Pdf/339.pdf $>$.

Olsson, G. 1960. Species crosses within the genus Brassica. II. Artificial Brassica napus. L. Hereditas 46:351-396.

Ordás, A. and J.J. Baladrón. 1985. Collecting Brassicas in northwestern Spain. Cruciferae Nwsl. 10:14.

Pkana, C.K., J.G. Wu, H.M. Xu, C.T. Li, and C.H. Si. 2007. Addressing rice germplasm genetic potential using genotypic value to develop quality core collections. J. Sci. Food Agr. 87:326-333.

Prakash, S. and K. Hinata. 1980. Taxonomy, cytogenetics and origin of crop Brassicas: A review. Opera Botanica 55:1-57. 
Rodríguez, V.M., M.E. Cartea, G. Padilla, P. Velasco, and A. Ordás. 2005. The nabicol: A horticultural crop in northwestern Spain. Euphytica 142:237-246.

Rohlf, F.J. 2000. NTSYS-PC numerical taxonomy and multivariate analysis system. Version 2.1. Exeter Publishing, Setauket, NY.

Sneath, P.H.A. and R.R. Sokal. 1973. Numerical taxonomy. Freeman, San Francisco, CA.

Soengas, P., P. Velasco, G. Padilla, A. Ordás, and M.E. Cartea. 2006. Genetic relationships among Brassica napus crops based on SSR markers. HortScience 41:1195-1199.
Song, K. and T.C. Osborn. 1992. Polyphyletic origins of Brassica napus: New evidence based on organelle and nuclear RFLP analyses. Genome 35:992-1001.

Song, K.M., T.C. Osborn, and P.H. Williams. 1988. Brassica taxonomy based on nuclear restriction fragment length polymorphisms (RFLPs). Theor. Appl. Genet. 75:784794.

Steel, R.D.G., J.H. Torrie, and D.A. Dickey. 1997. Principles and procedures in statistics: A biometrical approach. 3rd ed. McGraw Hill, New York. 